\title{
The Larva of Drusus nigrescens Meyer-Dür, 1875 (Trichoptera: Limnephilidae: Drusinae) with notes on its ecology, genetic differentiation and systematic position
}

\author{
J. Waringer ${ }^{1 *}$, W. Graf ${ }^{2}$, S. Pauls ${ }^{3}$, V. Lubini ${ }^{4}$ \\ ${ }^{1}$ Department of Freshwater Ecology, University of Vienna, Althanstraße 14, 1090 Vienna, Austria. \\ ${ }^{2}$ Institute of Hydrobiology and Aquatic Ecology Management, University of Natural Resources and Applied Life Sciences, Max Emanuelstraße \\ 17, 1180 Vienna, Austria. \\ ${ }^{3}$ Department of Limnology and Conservation, Senckenberg Research Institute, Clamecystraße 12, 63571 Gelnhausen, Germany. \\ ${ }^{4}$ Eichhalde 14, 8053 Zürich, Switzerland.
}

\begin{abstract}
The paper presents a description of the hitherto unknown larva of Drusus nigrescens Meyer-Dür, 1875. Information on the morphological and genetic identification of this species is given, and the most important diagnostic features are illustrated. Its systematic position within the genus Drusus is affirmed and some zoogeographical and ecological notes are added.
\end{abstract}

Keywords: Trichoptera, Drusus nigrescens, fifth instar larva, description, identification, distribution, ecology, mitochondrial DNA.

\section{Introduction}

So far, 24 Drusinae species are reported from Austria, Germany and Switzerland (Lubini \& Vicentini 2005; Malicky 1999, 2004; Robert 2001, 2004). Seven of them (Drusus alpinus (Meyer-Dür), D. chapmani McLachlan, D. franzi Schmid, D. improvisus McLachlan, D. melanchaetes McLachlan, D. nigrescens Meyer-Dür and D. noricus Malicky) are still unknown in the larval stage.

In the meantime, however, we managed to get larval specimens of D. nigrescens from Switzerland whose identity with the collected adults was confirmed by genetic analyses. This material enabled us to work out reliable diagnostic characters permitting integration of $D$. nigrescens in the key by Waringer \& Graf $(1997,2004)$.

\section{Material and methods}

Larvae which obviously were not yet included in existing Drusinae keys were collected from a spring brook in Switzerland where the dominant adult was $D$. nigrescens. To support species affiliation, larval and adult specimens were genetically analysed by means of DNA nucleotide sequence analysis following the methods outlined in Pauls (2004) and Pauls et al. (2006). A 498 base pair (bp) long section of the mtCOI region

\footnotetext{
* Corresponding author: E-mail : johann.waringer@univie.ac.at
}

revealed identical haplotypes between three previously unknown larvae with five adults of $D$. nigrescens $(3$ males, 1 female) from the same locality. One further male carried a haplotype which differed by one bp change. In Pauls (2004) a very close relationship between $D$. nigrescens and D. monticola was observed. We thus also generated mtCOI sequence data for 2 adults and 4 larvae of $D$. monticola and one adult of $D$. melanchaetes, a closely related species (Pauls 2004). We generated uncorrected pairwise distances between individuals using the DNADist function as implemented in BioEdit 7.0.5.3 (Hall 1999) (Table 1). No haplotypes were shared between species (Table 1). Haplotypes of $D$. nigrescens and D. monticola were, however, very close and interspecific uncorrected pairwise distance between haplotypes ( $p_{\text {nig/mon }}: 0.4-1.21 \%$ ) was not much higher than within species variability $\left(p_{\text {nig }}\right.$ : $\left.=0.4 \% ; p_{\text {mon }}:=0.82 \%\right)$ (Table 1$)$. To further elucidate the close relationship between haplotypes of D. nigrescens and D. monticola, a median joining (MJ) network (Bandelt et al. 1999) was computed using the default settings in Network 4.2 (Fluxus Technologies 2005) (Fig. 11). The network shows that, although the relationship between $D$. monticola (light grey) and $D$. nigrescens (black) is very close, the two species are delimited. The species also remain differentiated and monophyletic in a three gene phylogeny of the Drusinae (Pauls, unpublished data). 
Table 1. Specimen information, locality data and genetic differentiation of haplotypes observed in D. melanchaetes, D. monticola and D. nigrescens. Given are numbers of nucleotide differences (above diagonal) and p-distance (below diagonal) in pairwise comparisons of partial mtCOI.

\begin{tabular}{|c|c|c|c|c|c|c|c|c|c|c|c|c|c|c|c|c|c|c|c|}
\hline Drusus & Stage** & Locality & Haplotype & & & & & & & & & & & & & & & & $\begin{array}{l}\text { GenBank } \\
\text { Accession }\end{array}$ \\
\hline melanchaetes & $\mathrm{F}$ & $\begin{array}{l}\text { CH, East of Sustenpass, Nameless brook, } \\
18.07 .2004\end{array}$ & A & $\cdot$ & 36 & 36 & 38 & 39 & 38 & 38 & 36 & 36 & 36 & 36 & 36 & 36 & 36 & 36 & EF464555 \\
\hline monticola & $\mathbf{L}$ & AT, Soboth, Krumbach, 18.05 .2002 & B & 0.076 & - & 0 & 2 & 3 & 4 & 2 & 4 & 2 & 4 & 2 & 2 & 2 & 2 & 2 & EF464556 \\
\hline monticola & L & AT, Soboth, Krumbach, 18.05 .2002 & B & 0.076 & 0.000 & - & 2 & 3 & 4 & 2 & 4 & 2 & 4 & 2 & 2 & 2 & 2 & 2 & EF464557 \\
\hline monticola & $\mathbf{L}$ & AT, Saualpe, Offner Hutte, 30.06.2006 & C & 0.081 & 0.004 & 0.004 & - & 3 & 2 & 0 & 4 & 2 & 4 & 2 & 2 & 2 & 2 & 2 & EF464558 \\
\hline monticola & L & AT, Nockberge, St. Oswald Bach B, 01.07.2006 & D & 0.083 & 0.006 & 0.006 & 0.006 & - & 5 & 3 & 5 & 3 & 5 & 3 & 3 & 3 & 3 & 3 & EF464559 \\
\hline monticola & $\mathbf{F}$ & AT, Saualpe, Ladinger Hutte, 16.06.2006 & E & 0.081 & 0.008 & 0.008 & 0.004 & 0.010 & - & 2 & 6 & 4 & 6 & 4 & 4 & 4 & 4 & 4 & EF464560 \\
\hline monticola & $\mathbf{F}$ & AT, Saualpe, Ladinger Hutte, 16.06.2006 & C & 0.081 & 0.004 & 0.004 & 0.000 & 0.006 & 0.004 & $=$ & 4 & 2 & 4 & 2 & 2 & 2 & 2 & 2 & EF464561 \\
\hline nigrescens & M & $\mathrm{CH}$, Mutt and left tributaries, 17.07.2004 & $\mathbf{F}$ & 0.076 & 0.008 & 0.008 & 0.008 & 0.010 & 0.012 & 0.008 & $=$ & 2 & 2 & 2 & 2 & 2 & 2 & 2 & EF464562 \\
\hline nigrescens & $\mathbf{F}$ & $\mathrm{CH}$, Mutt and left tributaries, 17.07.2004 & G & 0.076 & 0.004 & 0.004 & 0.004 & 0.006 & 0.008 & 0.004 & 0.004 & - & 2 & 0 & 0 & 0 & 0 & 0 & EF464563 \\
\hline nigrescens & M & CH, Mutt and left tributaries, 17.07.2004 & H & 0.076 & 0.008 & 0.008 & 0.008 & 0.010 & 0.012 & 0.008 & 0.004 & 0.004 & - & 2 & 2 & 2 & 2 & 2 & EF464564 \\
\hline nigrescens & M & CH, Furka Pass 21.7. 2006 & G & 0.076 & 0.004 & 0.004 & 0.004 & 0.006 & 0.008 & 0.004 & 0.004 & 0.000 & 0.004 & - & 0 & 0 & 0 & 0 & EF464565 \\
\hline nigrescens & M & CH, Furka Pass 21.7. 2006 & G & 0.076 & 0.004 & 0.004 & 0.004 & 0.006 & 0.008 & 0.004 & 0.004 & 0.000 & 0.004 & 0.000 & - & 0 & 0 & 0 & EF464566 \\
\hline nigrescens* & $\mathbf{L}$ & CH, Furka Pass 21.7. 2006 & G & 0.076 & 0.004 & 0.004 & 0.004 & 0.006 & 0.008 & 0.004 & 0.004 & 0.000 & 0.004 & 0.000 & 0.000 & - & 0 & 0 & EF464567 \\
\hline nigrescens* & L & $\mathrm{CH}$, Mutt and left tributaries, 17.07.2004 & G & 0.076 & 0.004 & 0.004 & 0.004 & 0.006 & 0.008 & 0.004 & 0.004 & 0.000 & 0.004 & 0.000 & 0.000 & 0.000 & - & 0 & EF464568 \\
\hline nigrescens" & $\mathbf{L}$ & $\mathrm{CH}$, Mutt and left tributaries, 17.07.2004 & G & 0.076 & 0.004 & 0.004 & 0.004 & 0.006 & 0.008 & 0.004 & 0.004 & 0.000 & 0.004 & 0.000 & 0.000 & 0.000 & 0.000 & - & EF464569 \\
\hline
\end{tabular}

-F: female, M: male, L: larva
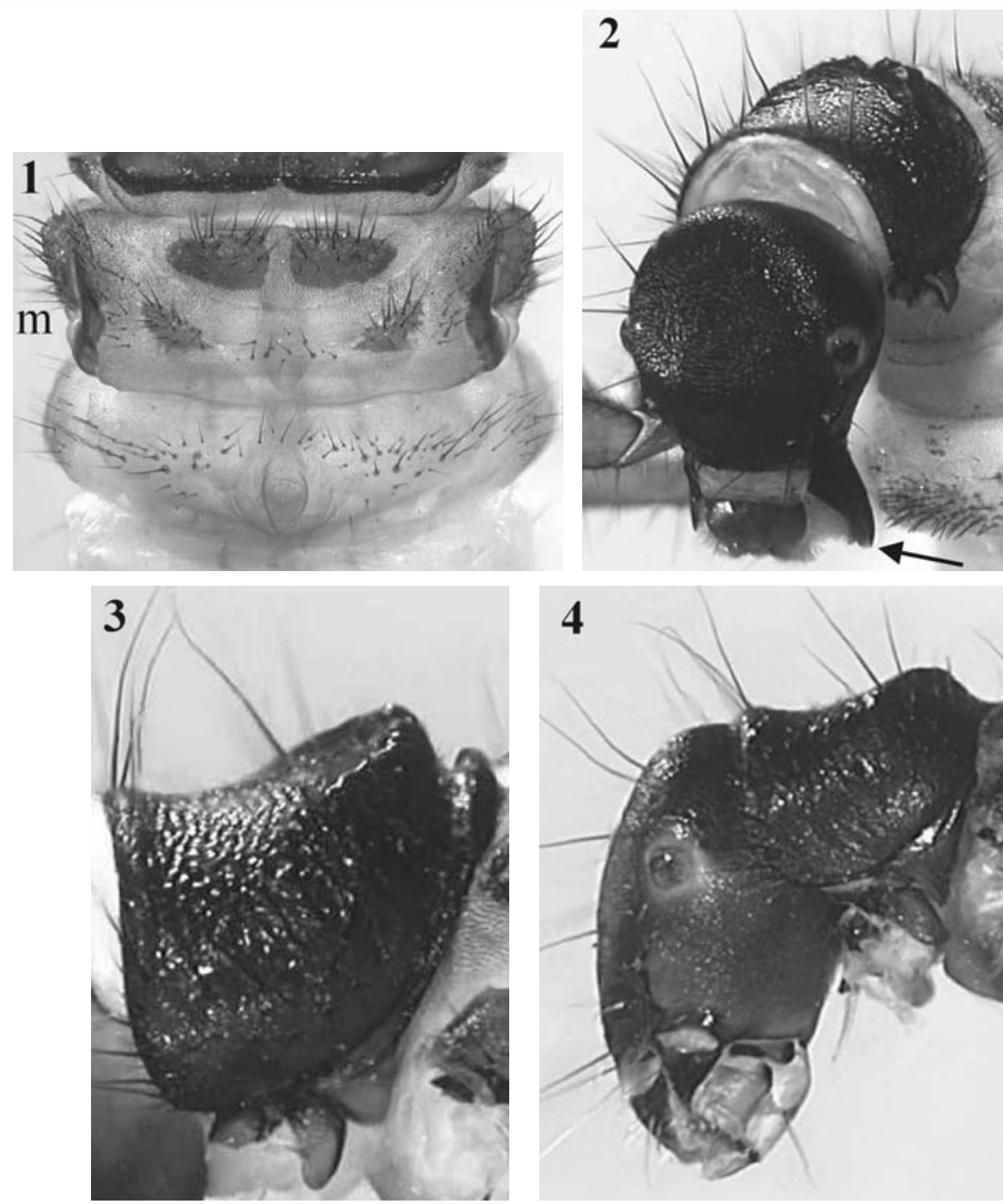

Figs1-4. Drusus nigrescens, fifth instar larva. 1: metathorax and first abdominal segment, dorsal view $(\mathrm{m}=6$ metanotal sclerites); 2: head and pronotum, antero-lateral view; arrow: spoon-shaped mandible with straight cutting edge; 3: pronotum, left lateral view; 4: Drusus monticola, head and pronotum, left lateral view. 


\section{Description of the fifth instar larva of Drusus nigrescens}

Material examined: Five fifth and five fourth instar larvae and 14 males and 15 females from the Furka$\mathrm{Pa}$, Switzerland $\left(46^{\circ} 35,3^{\prime} \mathrm{N}, 08^{\circ} 25,8^{\prime} \mathrm{E}, 2348 \mathrm{~m}\right.$ asl), collected by W.G; 2 males, 1 female and 2 larvae collected by S.P. (Table 1). Two females and 4 larvae of D. monticola, and the female of D. melanchaetes were collected from various sites by W.G. and S.P. (Table 1).

Body length of final instar larvae: $8.7-10.5 \mathrm{~mm}$; head width: $1.30-1.40 \mathrm{~mm}$ (head width of fourth instar larvae: $0.88-1.02$ ). Length of larval case: $7.5-8.2 \mathrm{~mm}$. The case is distinctly curved, tapering posteriorly (the mean width at anterior opening is $2.45 \mathrm{~mm}$ and at the posterior opening $1.45 \mathrm{~mm}$ ) and consists completely of mineral particles with grain sizes increasing distinctly in anterior direction.

Head capsule and all body sclerites dark brown to blackish brown. The head capsule (Fig. 2) lacks additional setae or spines that are typical in some other Drusinae larvae (e.g. Ecclisopteryx spp., Drusus trifi$d u s$ ). Mandibles lacking terminal teeth along edges as well as ridges in the central concavity (Fig. 2).

In profile, dorsal line of pronotum with a distinct ridge in its posterior third (Fig. 2,3) extending anterolaterally with its height decreasing (Fig. 3). The darkbrown pronotal surface is covered by black setae along the lateral borders, leaving the central pronotal area bare. Prosternite inconspicuous, prosternal horn present. Mesonotum completely covered by two chestnut brown sclerites. Metanotum partially covered by three pairs of sclerites; anterior metanotal sclerites large, ovoidal, their median separation being distinctly smaller than their maximum extension along the body axis (Fig. 1). Setal bases at the central section of the first abdominal sternum large and heavily concentrated, with a marked tendency of fusing, thereby creating a multilobed sclerotized pattern (Fig. 8). Overall setal counts at the sternum are up to 75, excluding the setal cover of the lateral protuberances. The sclerotized pattern is close to the structure observed in Metanoea rhaetica and M. flavipennis; however, the sclerotized plate in Metanoea is much less patchy and has a more clearly-defined outer border (Fig. 9) than in D. nigrescens.

Dorsal gills are present from the second (postsegmental position) to the fifth (postsegmental position). Ventral gills range from second (presegmental) to seventh segment (postsegmental). Lateral gills are present on the second and third segment (both in postseg- mental position). Lateral fringe present from the posterior third of third to the beginning of eighth abdominal segment.

Setae are present at anterior and posterior faces of all femora. The row of dorsal setae at the mid and hind legs extend, proximally, well over the half of the tibia (Fig. 7).
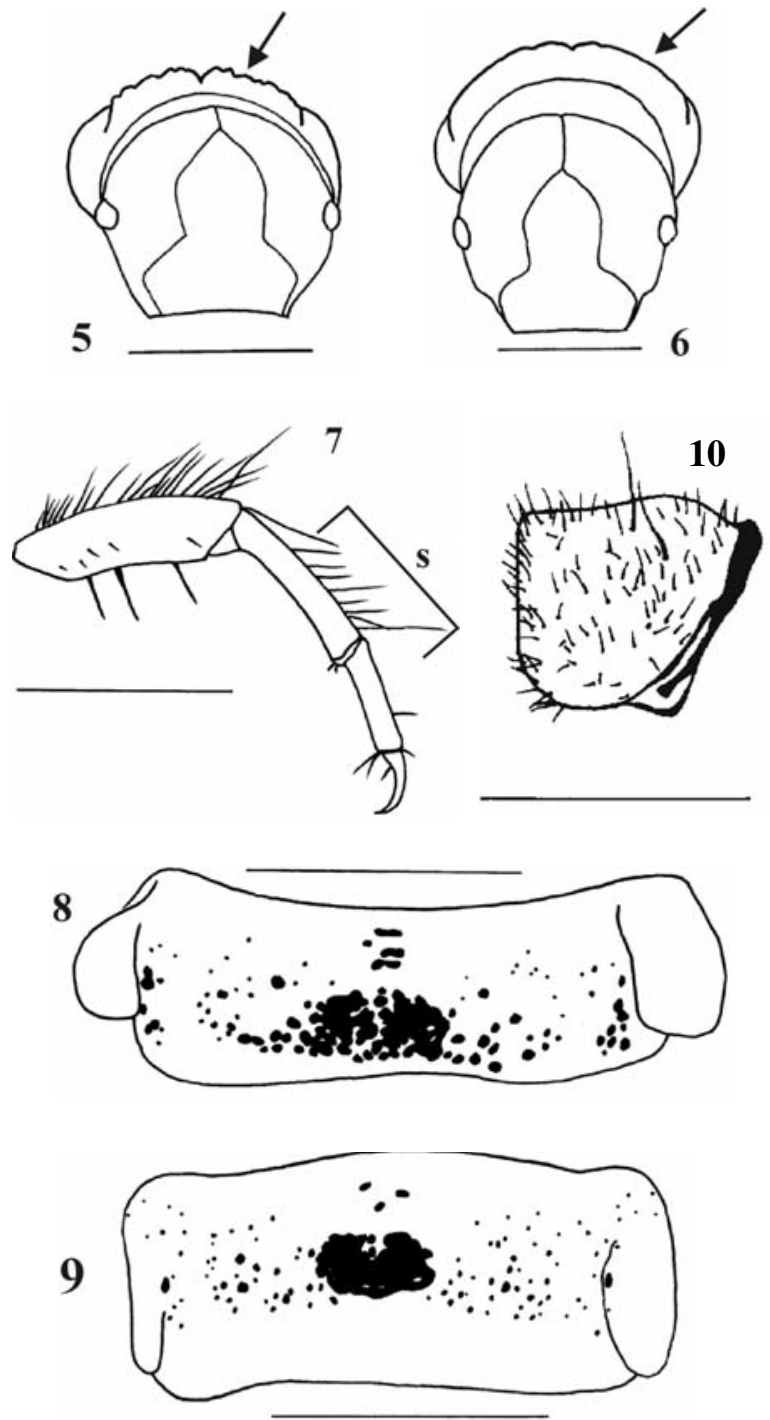

Figs 5-10. 5: Drusus nigrescens, head and pronotum, frontal view (arrow: serrated pronotal ridge); 6: Drusus monticola, head and pronotum, frontal view (arrow: smooth pronotal ridge); 7: Drusus nigrescens, right midleg, posterior face ( $\mathrm{s}=$ dorsal tibial setae); 8 : Drusus nigrescens, first abdominal sternum (black: sclerotized setal bases); Fig. 9 - 10: Metanoea flavipennis, fifth instar larva; 9: first abdominal sternum (black: sclerotized plate and setal bases); 10: pronotum, left lateral view. Scale bars: $1 \mathrm{~mm}$. 


\section{Morphological separation of Drusus nigren- cens from other European Trichoptera}

A summary of morphological features for the identification of limnephilid and Drusinae larvae is given in Waringer (1985). Within the framework of the limnephilid key by Waringer \& Graf (1997, 2004), Drusus nigrescens is separated from other species by the following features:

- metanotum covered by three pairs of small sclerites (Fig. 1, m);

- head and pronotum without a thick layer of woolly hairs (Fig 2);

- head capsule without groups of additional spines, without central concavity and rims surrounding the frontoclypeus (Fig. 2);

- first abdominal sternum with a large median sclerotized patch (Fig. 8);

- Mandibles without teeth around edges, spoonshaped (Fig. 2, arrow).

At this position $D$. nigrescens keys out together with Metanoea rhaetica and M. flavipennis, where D. nigrescens is easily separated from the Metanoea species by the presence of a distinct sharp pronotal rim (Fig. 3 ); in Metanoea, the dorsal line of the pronotum in profile is evenly rounded in its posterior third, thereby creating a small dorsal hump (Fig. 10; Waringer \& Graf 1997, 2004; Waringer, Graf \& Maier, 2000).

In case the sclerotized patch has been overlooked or interpreted as just an agglomeration of isolated setal bases, D. nigrescens keys out together with Drusus monticola (limnephilid key in Waringer \& Graf (1997, 2004). Here, both species can be easily identified by the structure of the pronotal ridge in lateral (Figs. 3 \& 4) and anterior view: in D. nigrescens, the ridge is serrate (Fig. 5), whereas in D. monticola the dorsal outline is smooth (Fig. 6). In addition, the dorsal setal fringes on the mid and hind tibiae are present within the proximal half of the tibiae (Fig. 7), whereas in D. monticola the setal fringes are restricted to the distal thirds of the tibiae. Finally, the agglomeration of sclerotized setal bases (Fig. 8) clearly identifies D. nigrescens; in $D$. monticola, sclerotized setal bases are few and widely separated.

\section{Habitat, phenology and distribution}

Last and penultimate instar larvae of $D$. nigrescens were collected on 21 July 2006 at the Furka-Paß, Switzerland $\left(46^{\circ} 35,3^{\prime} \mathrm{N}, 08^{\circ} 25,8^{\prime} \mathrm{E}, 2348 \mathrm{~m}\right.$ asl). The small, spring-fed, $50 \mathrm{~m}$ long, first order tributary is part of the Mutt watershed; it is a clean, fast-flowing, summer-cold, mountain brook bordered by meadows
(Fig. 12). At this location, D. nigrescens was sympatric with D. muelleri, Lithax niger and Plecoptera such as Dyctyogenus fontium, Protonemura lateralis, Leuctra ravizzai, L. rosinae, Nemoura mortoni and $N$. sinuata .

According to Malicky (2004), D. nigrescens is a western alpine species; records exist from Switzerland (Lubini-Ferlin \& Vicentini 2005) and Italy (Piemonte and Lombardia; Cianficconi 2002), but the species is lacking in Germany (Robert 2001, 2004). In addition, doubtful records of $D$. nigrescens are known from Poland as well as the Ukraine (Czachorowski, personal communication). In Austria, it is reported from the Tyrol only (Malicky 1999). D. nigrescens is on the wing from July to September.
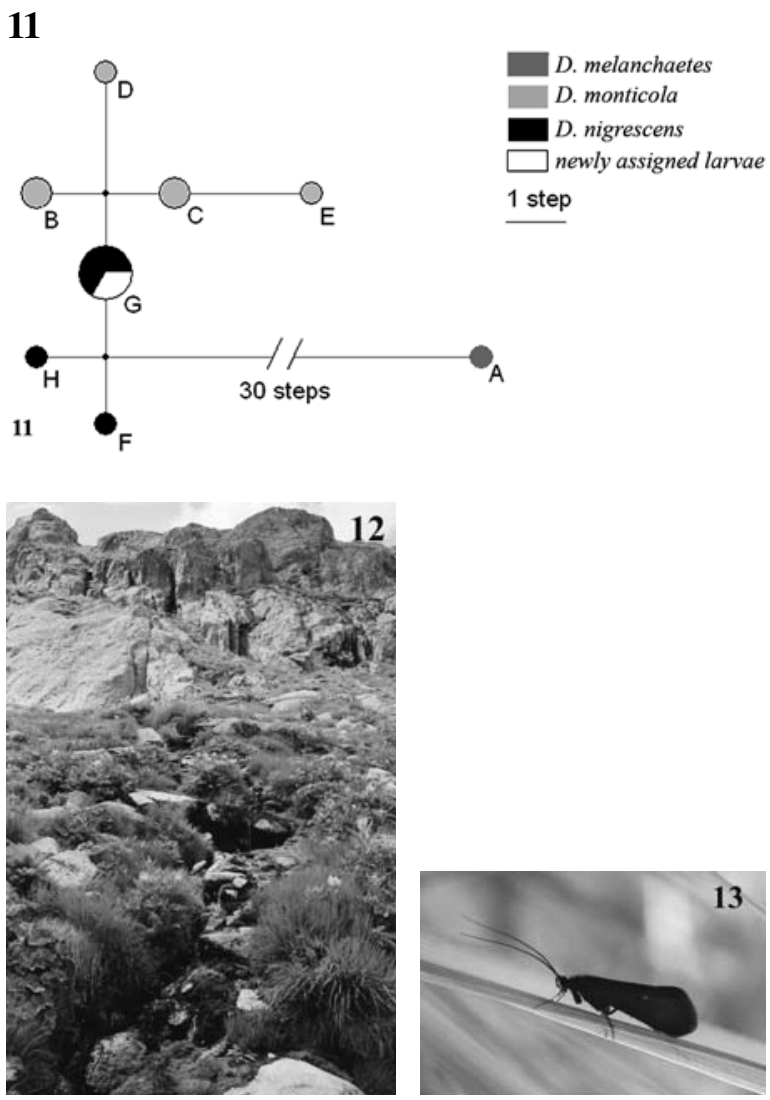

Figs 11-13. 11: Median-joining network of mtCOI haplotypes. Shaded circles represent haplotypes, haplotype names refer to Table 1. Shading coding indicates the species of specimens carrying a particular haplotype; diameter is relative to the number of specimens carrying a particular haplotype. Lines between haplotypes represent genetic distances between haplotypes; branch length is relative to distance, very long branches are shown with breaks. Small black circles represent median vectors. 12: View of the sampling site of $D$. nigrescens at the Furka-Paß, Switzerland, showing the small, spring-fed, first order tributary of the Mutt. 13: D. nigrescens, habitus of the coal-black male. 


\section{Discussion}

In his seminal work on the Drusinae, Schmid (1956) placed D. nigrescens within the bosnicus-group. Members of this group are dark brown in colour and have a large spinulated dorsal plate on the $8^{\text {th }}$ tergite. The superior appendices are relatively small. The intermediate appendices are relatively large, prominent and are turned toward one another, but remain distinct. The inferior appendices are prominent and very divergent. Schmid (1956) considers D. nigrescens a very close neighbour to $D$. monticola, which was confirmed in our analysis of mtCOI in this study and in a preliminary phylogeny on the group (Pauls 2004). In fact our results show that, although both the larval and adult stages allow for clear morphological distinction, that divergence between the two species is minimal. The two species and their distinct morphologies are presumably the result of a very recent speciation event. More detailed molecular and morphological phylogenetic analyses are necessary to elucidate this divergence in more detail.

Schmid (1956) and Malicky (1983) illustrated both species, and greatly improved drawings of $D$. monticola and D. nigrescens are included, side by side, in Malicky (2004) together with the remark that identification is difficult. Although minute differences in both sexes are quite clearly shown in the latter publication, we add figures of the male and female genitalia, redrawn from own material (Figs. 14-17), to facilitate separation. Besides genitalia the most striking character is the general appearance, which is not shown anywhere. D. nigrescens is black as coal (Fig. 13) whereas D. monticola is brownish and much paler.

The current study presents the second example of a larval description based on molecular matching with adult caddisflies of the Drusinae (e.g. Graf et al. 2005). Molecular associations between sexes or life stages are becoming more commonplace in caddisflies (Shan et al. 2004) and other insect groups (e.g. Miller et al. 2005, Willassen 2005), exemplifying how nucleotide sequence markers can facilitate and provide supportive evidence in taxonomic and systematic research. However our study also shows the potential limits of using only DNA based-taxonomy between extremely closely related species, especially if lineage sorting is still incomplete (Pamilo \& Nei 1988, Morando et al. 2004). The use of a single mitochondrial gene region as proposed for "DNA barcoding" may not be sufficient to resolve such situations, and the choice of the marker of utmost importance (Mueller 2006).
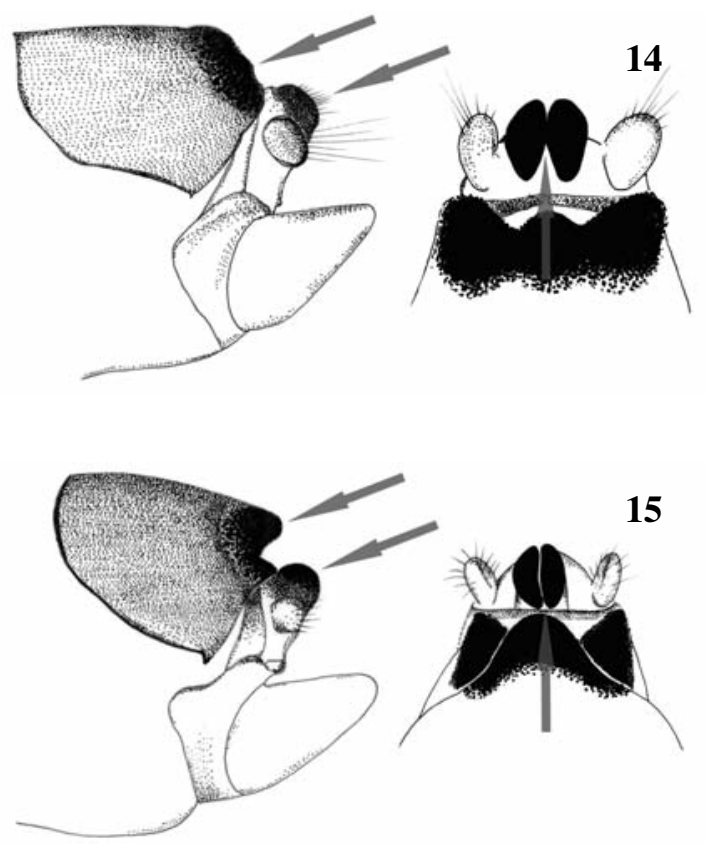

Figs. 14-15. Male genitalia (left lateral and dorsal view): Fig. 14: Drusus monticola; Fig. 15: D. nigrescens. The most important diagnostic characters are marked by arrows.

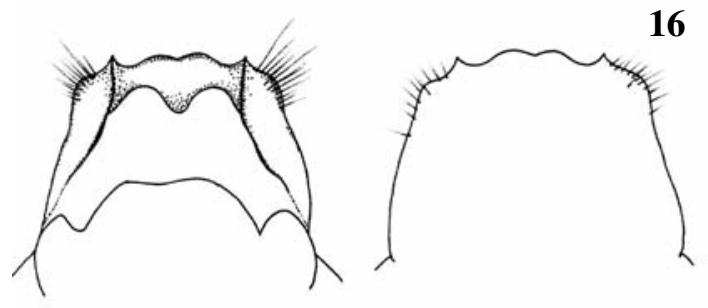

17

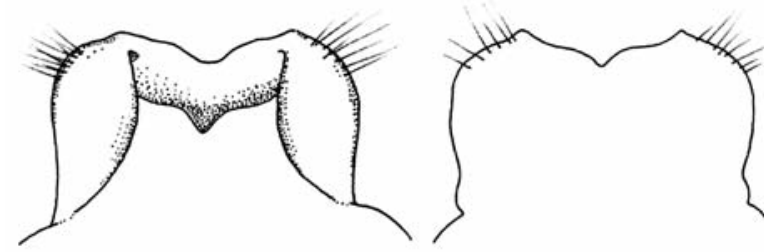

Figs 16-17. Female genitalia (ventral and dorsal view): Fig. 16: Drusus monticola; Fig. 17: D. nigrescens. 


\section{Acknowledgements}

We wish to thank Mag. Philipp Wenzl for his assistance and Dr. W. Lechtaler for providing the photographs as well as Dr. Czachorowski for his comments on distribution. This paper is part of the outcomes of a project dealing with larval taxonomy of Central European Drusinae (project number P18073-B03, PI: J. Waringer) funded by the Austrian Science Fund (FWF)

\section{References}

Bandelt H.J., Forster P. \& Röhl A. 1999. - Median-Joining Networks for Inferring Intraspecific Phylogenies. Mol. Biol. Evol., 16, 37-48.

Cianficconi F. 2002. - The third list of Italian Trichoptera (19902000). Proceedings of the $10^{\text {th }}$ International Symposium on Trichoptera - Nova Supplementa Entomologica, Keltern 15 (2002), 349-358.

Graf W., Lubini V. \& Pauls S. 2005. - Larval description of Drusus muelleri McLachlan, 1868 (Trichoptera: Limnephilidae) with some notes on its ecology and systematic position within the genus Drusus. Ann. Limnol. - Int. J. Lim., 41, 93-98.

Hall T.A. 1999. - BioEdit: a user-friendly biological sequence alignment editor and analysis program for Windows 95/98/NT. Nucleic Acids Symposium Series, 41, 95-98.

Lubini-Ferlin V. \& Vicentini H. 2005. - To the knowledge of the Swiss caddis fly fauna (Insecta: Trichoptera). Lauterbornia, 54, 63-79.

Malicky H. 1999. - Eine aktualisierte Liste der österreichischen Köcherfliegen (Trichoptera). Braueria, 26, 31-40.

Malicky H. 1983. - Atlas of European Trichoptera. Junk Publishers, 298pp.

Malicky H. 2004. - Atlas of European Trichoptera. Second edition. Springer, 359pp.

Miller K.B., Alarie Y., Wolfe G.W. \& Whiting M.F. 2005. - Association of insect life stages using DNA sequences: the larvae of Philodytes umbrinus (Motschulsky) (Coleoptera: Dytiscidae). Syst. Entomol., 30, 499-509.

Morando M., Avila L.J., Baker J. \& Sites J.W. 2004. - Phylogeny and phylogeography of the Liolaemus darwinii complex (Squamata: Liolaemidae): Evidence for introgression and incomplete lineage sorting. Evolution, 58, 842-861.
Mueller R.L. 2006. - Evolutionary Rates, Divergence Dates, and the Performance of Mitochondrial Genes in Bayesian Phylogenetic Analysis. Syst. Biol., 55, 289-300.

Pamilo, P. \& Nei, M. 1988. Relationships between gene trees and species trees. Mol. Biol. Evol., 5, 569-583.

Pauls S. 2004. - Phylogeny and phylogeography of the montane caddis fly Drusus discolor (Rambur, 1842) (Trichoptera: Limnephilidae, Drusinae). PhD-Thesis, University of Duisburg-Essen. 1-164.

Pauls S.U., Lumbsch H.T. \& Haase P. 2006. - Phylogeography of the montane caddisfly Drusus discolor: evidence for multiple refugia and periglacial survival. Mol. Ecol., 15, 2153-2169.

Robert B. 2001. - Verzeichnis der Köcherfliegen (Trichoptera) Deutschlands. Die Köcherfliegen-Fauna Deutschlands: Ein kommentiertes Verzeichnis mit Verbreitungsangaben. In: Klausnitzer, B. (Hrsg.), Entomofauna Germanica 5-Entomologische Nachrichten und Berichte (Dresden), Beiheft 6, 107-151.

Robert B. 2004. - Systematisches Verzeichnis der Köcherfliegen (Trichoptera) Deutschlands Fortschreibung 02/2004. Entomologie heute 16, 93-107.

Schmid F. 1956. - La sous-famille des Drusinae (Trichoptera, Limnephilidae). Mem. Inst. Roy. des Sci. Nat. de Belgique, $2^{e}$ Series, $55,1-92$.

Shan L., Yang L. \& Wang B. 2004. - Association of larval and adult stages of ecologically important caddisfly (Insecta: Trichoptera). Zool. Res., 45, 351-355.

Waringer J. 1985. - The larva of Metanoea rhaetica Schmid, 1955 (Trichoptera:Limnephilidae: Drusinae) from a small Austrian mountain brook. Aquat. Insect., 7, 243 -248.

Waringer J. \& Graf W. 1997. - Atlas der Österreichischen Köcherfliegenlarven . Facultas Univeritätsverlag, Wien, 286pp.

Waringer J., Graf W. \& Maier K.-J. 2000. - The larva of Metanoea flavipennis Pictet, 1834 (Trichoptera: Limnephilidae: Dusinae). Aquat. Insect., 22, 66-70.

Waringer J. \& Graf W. 2004. - Ergänzungen und Berichtigungen zum „Atlas der österreichischen Köcherfliegenlarven unter Einschluß der angrenzenden Gebiete“. Beilage zum 2. unveränderten Nachdruck. Facultas Universitätsverlag, Wien, 28pp.

Willassen E. 2005. - New species of Diamesa (Diptera: Chironomidae) from Tibet: conspecific males and females associated with mitochondrial DNA. Zootaxa, 1049: 19-32. 